\title{
Prolaris Prostate Cancer Testing
}

National Cancer Institute

\section{Source}

National Cancer Institute. Prolaris Prostate Cancer Testing. NCI Thesaurus. Code C150175.

A proprietary prognostic test which directly measures tumor cell growth characteristics for stratifying the risk of disease progression in prostate cancer patients. It provides a measure of the aggressiveness of an individual's prostate cancer and predicts diseasespecific mortality. 